\title{
Article \\ Chemical Composition and Corrosion Behavior of a-C:H/DLC Film-Coated Titanium Substrate in Simulated PEMFC Environment
}

\author{
Beibei Han ${ }^{1,2}$, Mengyuan Yan ${ }^{2}$, Dongying Ju ${ }^{3,4,5, *}$, Maorong Chai ${ }^{3,6}$ and Susumu Sato ${ }^{2}$ \\ 1 Ningbo Institute of Materials Technology and Engineering, Chinese Academy of Sciences, \\ Ningbo 315201, China; beibei_han@163.com \\ 2 Graduate School of Engineering, Saitama Institute of Technology, Fukaya 369-0203, Japan; \\ sjzyanmengyuan@163.com (M.Y.); ssato@sit.ac.jp (S.S.) \\ 3 Advanced Science Institute, Saitama Institute of Technology, Fukaya 369-0203, Japan; \\ chaimaorong@spic.com.cn \\ 4 Ningbo Haizhi Institute of Material Industry Innovation, Ningbo 315000, China \\ 5 Tokyo Green Power Electric Research Institute Co., Ltd., Tokyo 111-0022, Japan \\ 6 State Power Investment Corporation, Beijing 102209, China \\ * Correspondence: dyju@sit.ac.jp; Tel.: +81-048-585-6902
}

Citation: Han, B.; Yan, M.; Ju, D.; Chai, M.; Sato, S. Chemical Composition and Corrosion Behavior of a-C:H/DLC Film-Coated Titanium Substrate in Simulated PEMFC Environment. Coatings 2021, 11, 820. https://doi.org/10.3390/ coatings 11070820

Academic Editor: Octavian Buiu

Received: 6 May 2021

Accepted: 31 May 2021

Published: 7 July 2021

Publisher's Note: MDPI stays neutral with regard to jurisdictional claims in published maps and institutional affiliations.

Copyright: (c) 2021 by the authors. Licensee MDPI, Basel, Switzerland. This article is an open access article distributed under the terms and conditions of the Creative Commons Attribution (CC BY) license (https:// creativecommons.org/licenses/by/ $4.0 /)$.

\begin{abstract}
The amorphous hydrogenated (a-C:H) film-coated titanium, using different $\mathrm{CH}_{4} / \mathrm{H}_{2}$ and deposition times, was prepared by the ion beam deposition (IBD) method, which has the advantage of high adhesion because of the graded interface mixes at the atomic level. The chemical characterizations and corrosion behaviors of a-C:H film were investigated and evaluated by SEM, AFM, Raman spectroscopy, EPMA, TEM and XPS. An a-C:H film-coated titanium was corroded at $0.8 \mathrm{~V}, 90{ }^{\circ} \mathrm{C}$ in a $0.5 \mathrm{~mol} / \mathrm{L} \mathrm{H}_{2} \mathrm{SO}_{4}$ solution for $168 \mathrm{~h}$. The metal ion concentration in the $\mathrm{H}_{2} \mathrm{SO}_{4}$ corrosion solution and the potentiodynamic polarization behavior were evaluated. Results indicate that a higher $\mathrm{CH}_{4} / \mathrm{H}_{2}$ of 1:0 and a deposition time of $12 \mathrm{~h}$ can result in a minimum $\mathrm{I}_{\mathrm{D}} / \mathrm{I}_{\mathrm{G}}$ ratio of 0.827 , Ra of $5.76 \mathrm{~nm}$, metal ion concentration of $0.34 \mathrm{ppm}$ in the corrosion solution and a corrosion current of $0.23 \mu \mathrm{A} / \mathrm{cm}^{2}$. The current density in this work meets the DOE's 2020 target of $1 \mu \mathrm{A} / \mathrm{cm}^{2}$. Electrical conductivity is inversely proportional to the corrosion resistance. The significant improvement in the corrosion resistance of the a-C:H film was mainly attributed to the increased $s p^{3}$ element and nanocrystalline $\mathrm{TiC}$ phase in the penetration layer. As a result, the a-C:H film-coated titanium at $\mathrm{CH}_{4} / \mathrm{H}_{2}=1: 0$ with improved anti-corrosion behavior creates a great potential for PEMFC bipolar plates.
\end{abstract}

Keywords: a-C:H film; titanium substrate; chemical structure; corrosion behavior

\section{Introduction}

A fuel cell can be regarded as a kind of equipment, which can directly convert the chemical energy of a fuel into electrical energy with zero emissions [1]. With good efficiency, low operating temperature and clean technology, polymer electrolyte membrane fuel cell (PEMFC) is proposed as one of the most prospective power sources for residential and commercial applications. As the important component of hydrogen fuel cells, bipolar plates must be made of permeability materials, be anti-corrosive, electrically conductive between adjacent cells, have a uniform feed gas diffusion and product removal capacity, be of low cost and be economically viable to manufacture [2]. Traditional bipolar plates are made of graphite material. However, the brittleness and high cost of graphite are considered to be major barriers to its mass production [3]. Instead, metal bipolar plates, such as stainless steel, titanium and aluminum alloys, are used [4-6]. The conductivity of metallic bipolar plates is a vital requirement. The low electrochemical impedance of metallic bipolar plates indicates the high performance of PEMFC. Under the PEMFC acid environment, the metal 
bipolar plate is prone to reaction with electrolyte solution, leading to the dissolution of metal ions. The dissolved metal ions are absorbed by the polymer electrolyte membrane and decrease catalytic activity, which can affect the efficiency of PEMFC [7]. In addition, the lower working potential can easily generate an oxidation film on the surface of metal bipolar plates at the cathode side [8]. The thin passivation layer offers poor conductivity, resulting in a lower output power of fuel cells. Thus, some modification of the material surface has been developed to improve these properties.

The deposition of the DLC film as a protective coating is a promising solution to protect the metallic bipolar plate from a harsh acid operation condition. There are several studies about the deposition method of DLC film, such as sputtering deposition, plasma enhanced chemical vapor deposition (PECVD), ion beam deposition (IBD), cathodic vacuum arc deposition (CVA) and other techniques [9]. In the deposition process, impurities present on the surface of the sample are also coated with the DLC film along with the sample. When the plasma supply is stopped, the impurities and substrate with different thermal expansion coefficients return to the original state, resulting in the presence of pinholes in the DLC film [10]. Due to the processing temperature of IBD, it can be held below $93^{\circ} \mathrm{C}$ $\left(200^{\circ} \mathrm{F}\right)$ and no such pinholes are produced on the surface. The IBD is a physical thin film technique that achieves a high degree of precision and uniformity via the simultaneous bombardment of energetic atomic particles. Therefore, the improved film performance, such as high interfacial adhesion, high density, smooth surface morphology and low internal stresses, are obtained by the IBD method. Toro et al. proposed a DLC coating using a PECVD method as the protective film to improve anti-corrosion properties [11]. Wang et al. prepared a dense polypyrrole film on SUS316L to resist corrosion by galvanostatic and cyclic voltammetric methods [12]. Some researchers have developed noble metal film on titanium bipolar plates by pulsed bias arc ion plating, such as $\mathrm{Au}$ and $\mathrm{Ag}$, which have a prominent corrosion resistance but easily form an oxide layer and are expensive [13,14]. We prepared DLC film on the SUS316L substrate as the protective coating against corrosion in our previous works, which found that the stainless steel still has intergranular corrosion under a long-term high temperature and acidic environment [15]. Liu et al. applied the magnetron sputtering method to deposit $\mathrm{CrCuAgN}$ film onto the metallic bipolar plate [16] However, there is little publication about the DLC film deposition on metallic bipolar plates using the IBD technique.

In this paper, a-C:H/DLC film was deposited on titanium substrate by the ion beam deposition method with different gas ratios $\mathrm{CH}_{4} / \mathrm{H}_{2}$ and deposition times as bipolar plates for PEMFC. The chemical characteristics, interfacial contact resistance and electrochemical corrosion behavior of the a-C:H film-coated titanium substrate were evaluated in a simulated PEMFC environment.

\section{Materials and Methods}

The IBD method combines the advantages of chemical and thermal processes. A schematic diagram of DLC film deposition using the IBD method is presented in Figure 1. In the first step, the hydrocarbon source mixture is ionized by an accelerating voltage [17]. The ionized hydrocarbon ions are accelerated to form ion beam plasma, such as $\mathrm{CH}_{5}{ }^{+}, \mathrm{H}^{+}$and $\mathrm{CH}_{3}{ }^{+}$ ions. In the second stage, the coating atoms form the case layer after penetrating the $\mathrm{Ti}$ surface. Several reactions take place in surface processes, such as adsorption, direct incorporation of ions, reemission of $\mathrm{H}$, surface etching and sputtering, in the deposition process of $\mathrm{a}-\mathrm{C}: \mathrm{H}$ coatings [18]. The a-C:H coating properties are improved with the graded interfacial layer, leading to the improvement of adhesion and reduction of internal stresses [19]. 


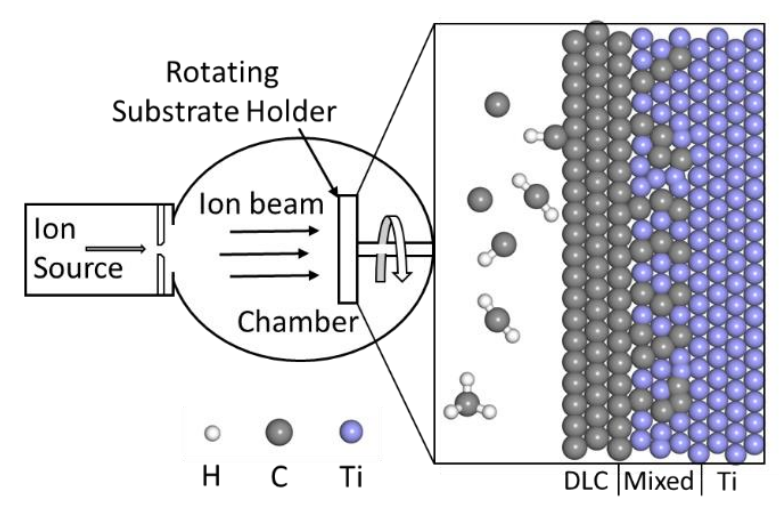

Figure 1. Deposition schematic diagram of DLC film by IBD method.

The substrate material was titanium cut into dimensions of $100 \mathrm{~mm}(\mathrm{~L}) \times 100 \mathrm{~mm}(\mathrm{~W})$ $\times 0.1 \mathrm{~mm}(\mathrm{H})$. All the samples were polished with waterproof paper (\#2000), ultrasonically cleaned with acetone for $10 \mathrm{~min}$, dried and fixed onto the rotating substrate holder in the ion implantation system chamber as shown in Figure 1. Before deposition, the chamber was evacuated to $4 \times 10^{-4} \mathrm{~Pa}$ for plasma discharge. After that, a mixture of $\mathrm{CH}_{4}$ and $\mathrm{H}_{2}$ gas was introduced into the chamber to make the chamber pressure stabilized at $2 \times 10^{-3} \mathrm{~Pa}$. The deposition time of the film was set to $6 \mathrm{~h}$ and $12 \mathrm{~h}$. The current, accelerating voltage and gas flow were set at $40 \mathrm{~mA}, 9 \mathrm{kV}$ and $0.5 \mathrm{sccm}$ for all the samples, respectively. Finally, after deposition, all the titanium substrates coated with DLC films were cooled down inside the chamber. Table 1 shows the a-C:H films at different conditions.

Table 1. Parameters of different processing conditions.

\begin{tabular}{cccccc}
\hline Substrate & \multicolumn{5}{c}{ Titanium } \\
\hline $\begin{array}{c}\mathrm{CH}_{4} / \mathrm{H}_{2} \\
\text { Deposition time }\end{array}$ & $6 \mathrm{~h}$ & $1: 1$ & $12 \mathrm{~h}$ & $6 \mathrm{~h}$ & $1: 0$ \\
\hline
\end{tabular}

The micromorphological characterization and surface roughness of the coatings were investigated by a HITACHI-TM3000 scanning electron microscope (SEM) (Hitachi Ltd., Tokyo, Japan) and an SPM-9500J3 atomic force microscopy (AFM) (Shimadzu Ltd., Kyoto, Japan). The samples used for the transmission electron microscopy (TEM) (Hitachi Ltd., Tokyo, Japan) and the SEM were prepared by a focused ion beam (FIB) with a JIB-4500 Multi Beam System (JEOL Ltd., Akishima-shi, Japan). The chemical composition of the cross-section was observed by a JXA-8900R electron probe microanalysis (EPMA) (JEOL Ltd., Akishima-shi, Japan). The DLC film microstructural characterization and element composition were determined by an NRS-4100 Raman measurement (JASCO Inc., Easton, PA, USA) with a laser wavelength of $532.0 \mathrm{~nm}$, a HF-3300 TEM and a Physical Electronics (PHI) Quantum 2000 X-ray photoelectron spectroscopy (XPS) (Pleasanton, CA, USA) equipped with a monochromatic $\mathrm{Al} \mathrm{K} \alpha \mathrm{X}$-ray excitation source and an energy of $1486.6 \mathrm{eV}$. The working conditions of $12 \mathrm{~mA}$ and $13 \mathrm{kV}$ were employed. The base pressure of the chamber was about $1.33 \times 10^{-7} \mathrm{~Pa}$. All the spectra were collected at $20 \mathrm{eV}$ pass energy to ensure an energy resolution of $1.0 \mathrm{eV}$ and high sensitivity. The ICR of the DLC films coated on titanium was measured by a conventional test mentioned in the previous literature [20].

The anti-corrosion property is an important factor for evaluating the performance of bipolar plates. Thus, the DLC film-coated titanium was corroded by potentiostatic polarizations in a $0.5 \mathrm{~mol} / \mathrm{L} \mathrm{H}_{2} \mathrm{SO}_{4}$ solution at $90{ }^{\circ} \mathrm{C}$ for one week. The corrosion measurement is illustrated in Figure 2. The precipitated titanium ions in the $\mathrm{H}_{2} \mathrm{SO}_{4}$ solution were detected by inductively coupled plasma atomic emission spectroscopy (ICPS-7000) (Shimadzu Ltd., Kyoto, Japan) after the corrosion test. The electrochemical performance of the a-C:H film deposited on the titanium was investigated in $0.5 \mathrm{~mol} / \mathrm{L} \mathrm{H}_{2} \mathrm{SO}_{4}$ solution at $90{ }^{\circ} \mathrm{C}$ by a conventional three-electrode method reported in [21]. The DLC film-coated 
specimen, platinum wire and saturated calomel electrode (SCE) acted as the working electrode, counter electrode and reference electrode, respectively. The test sample was exposed to the corrosive solution on one side with an area of $10 \times 10 \mathrm{~mm}^{2}$ while the other side was sealed.

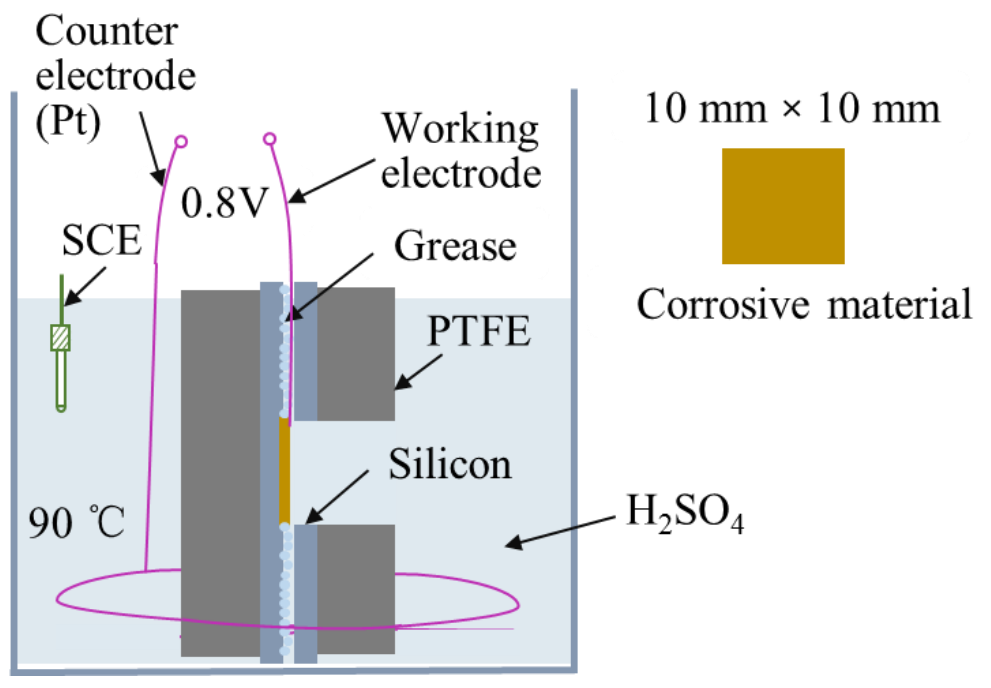

Figure 2. Schematic diagram of corrosion test.

\section{Results and Discussions}

\subsection{Surface Topography}

The surface topography of the uncoated titanium and the DLC film-coated titanium substrates were observed through AFM and SEM, and the photos are presented in Figure 3, which shows that the a-C:H coatings are dense and composed of spherical particles on the entire specimen surface, with diameters of $0.2 \mu \mathrm{m} \sim 1.6 \mu \mathrm{m}$. The surface morphology of a-C:H coatings deposited at $\mathrm{CH}_{4} / \mathrm{H}_{2}=1: 0$ presents a smoother surface and a smaller granularity than that of a-C: $\mathrm{H}$ coatings at $\mathrm{CH}_{4} / \mathrm{H}_{2}=1: 1$, which means that the high $\mathrm{CH}_{4}$ fraction is positive for the smooth surface morphology with nearly no pinholes. According to Ortiz-Medina [22], the increasing of $\mathrm{CH}_{4}$ would change the surface topography. Titanium substrate can be protected from the sulfuric acid solution by depositing dense a-C:H coatings. From the surface microstructure, the high $\mathrm{CH}_{4}$ fraction and long depositing time are more favorable to the denser a-C:H coatings.

Figure 4 shows the AFM pictures and average roughness values of the DLC film coated on titanium with random areas of $2 \mu \mathrm{m} \times 2 \mu \mathrm{m}$. As shown in Figure $4 \mathrm{a}-\mathrm{e}$, the undulating hills appear on the surface of the bare specimen and DLC films with a height of about $158.21 \mathrm{~nm}, 126.26 \mathrm{~nm}, 68.48 \mathrm{~nm}, 91.75 \mathrm{~nm}$ and $66.03 \mathrm{~nm}$, respectively. The average roughness $\mathrm{Ra}$ values of the a-C: $\mathrm{H}$ coatings at $\mathrm{CH}_{4} / \mathrm{H}_{2}=1: 0(7.38 \mathrm{~nm}$ and $5.76 \mathrm{~nm})$ are lower than that of DLC films at $\mathrm{CH}_{4} / \mathrm{H}_{2}=1: 1(8.98 \mathrm{~nm}$ and $6.95 \mathrm{~nm})$. All of them are lower than the Ra of the uncoated titanium surface $(14.01 \mathrm{~nm})$. This is because during the deposition process, upon implantation of the hydrocarbon ions, they conveyed substantial energy to the film for substrate heating. The process of substrate heating provides a denser and more uniform coating. The undulating hills are more flattened with the increasing methane fraction, which has a higher $s p^{3}$ ratio, and an increase in the hydrogen fraction leads to an increase in the surface roughness; these may be caused by the etching effect [23]. Liang et al. [24] believed that hydrogen etching was a variable that affects the average roughness. The Ti specimen would be destroyed under the process of deposition. Moreover, the incident $\mathrm{CH}_{\mathrm{x}}$ group ions can form $s p^{2}$ and $s p^{3}$ hybridizations following the chemical reaction on the Ti substrate surface. Many $s p^{2} \mathrm{C}$ and $s p^{3} \mathrm{C}$ structures result in the growth of $\mathrm{CH}_{\mathrm{x}}$ group ions on the substrate surface. However, the $\mathrm{H}$ ions/atoms/molecules that promoted $\mathrm{sp}^{3}$ hybridization contribute to the growth of the $\mathrm{CH}_{\mathrm{x}}$ groups on the substrate 
surface. Therefore, the competition between the $\mathrm{CH}_{\mathrm{x}}$ groups and $\mathrm{H}$ ions/atoms/molecules, as well as the etching and growth effects on the substrate surface must be taken into consideration. There is an abundance of dangling $\mathrm{C}$ bonds on the substrate surface due to the small amounts of $\mathrm{H}$ groups in the ion beam. Incident $\mathrm{CH}_{\mathrm{x}}$ group ions grow on the substrate surface because the dangling carbon bond on the surface could not be totally saturated. Hence, with the $\mathrm{CH}_{4}$ ratio increases, the growth effect dominates the deposition process, which leads to a smoother specimen. The AFM result corresponded to the SEM surface analysis.
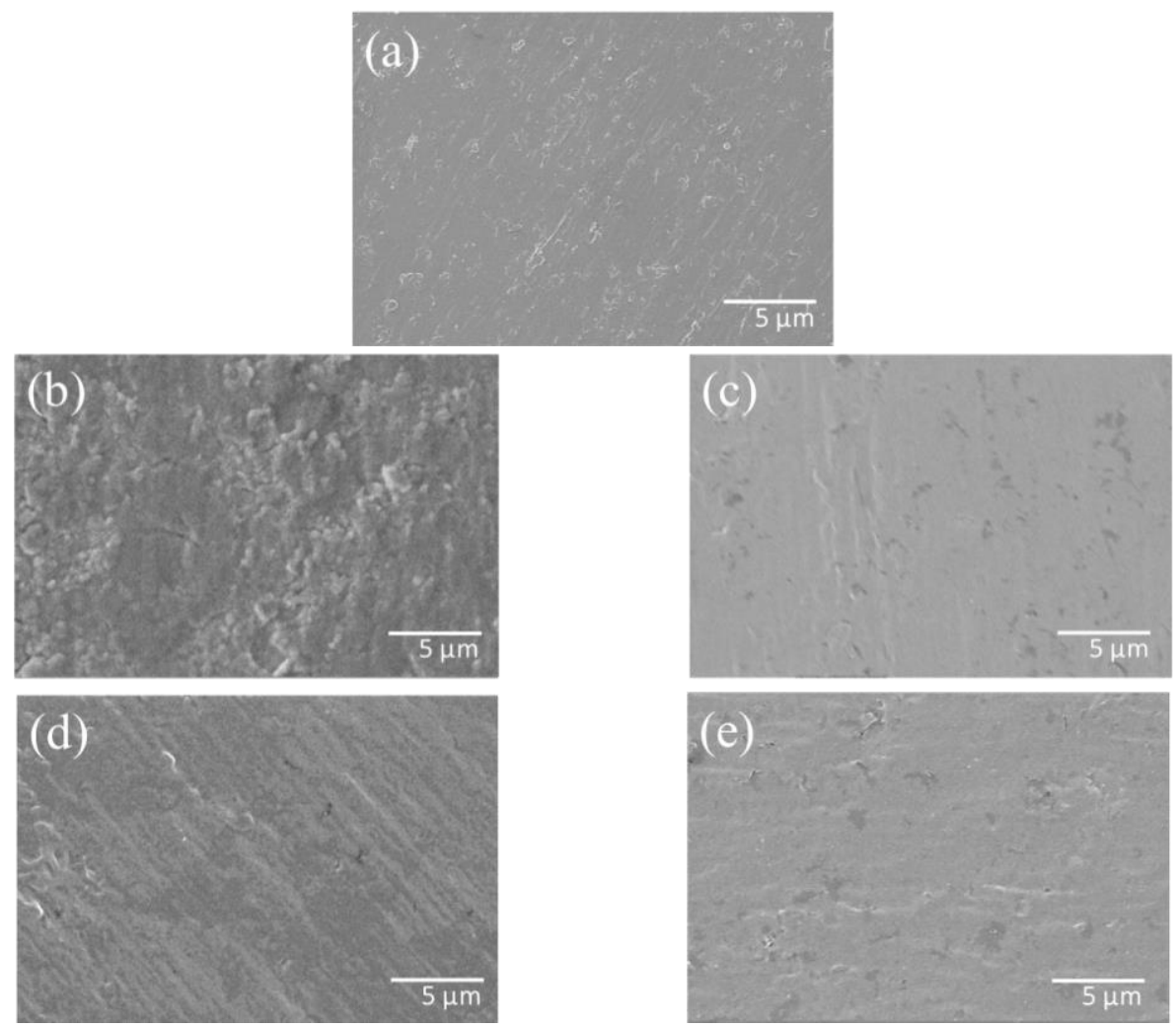

Figure 3. SEM micrographs of uncoated titanium surface (a) and DLC film-coated titanium deposited at $\mathrm{CH}_{4} / \mathrm{H}_{2}=1: 1(\mathbf{b}) ; \mathrm{CH}_{4} / \mathrm{H}_{2}=1: 1(\mathbf{c}) ; \mathrm{CH}_{4} / \mathrm{H}_{2}=1: 0(\mathbf{d}) ; \mathrm{CH}_{4} / \mathrm{H}_{2}=1: 0$ (e), with the deposition times of $6 \mathrm{~h}, 12 \mathrm{~h}, 6 \mathrm{~h}$ and $12 \mathrm{~h}$, respectively.

(a) $\mathrm{Ra}=14.01 \mathrm{~nm}$

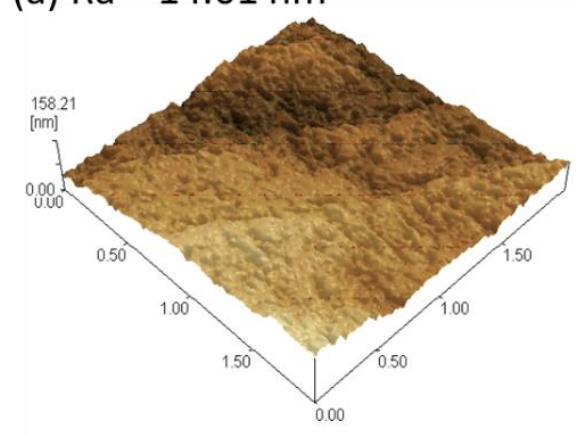

Figure 4. Cont. 

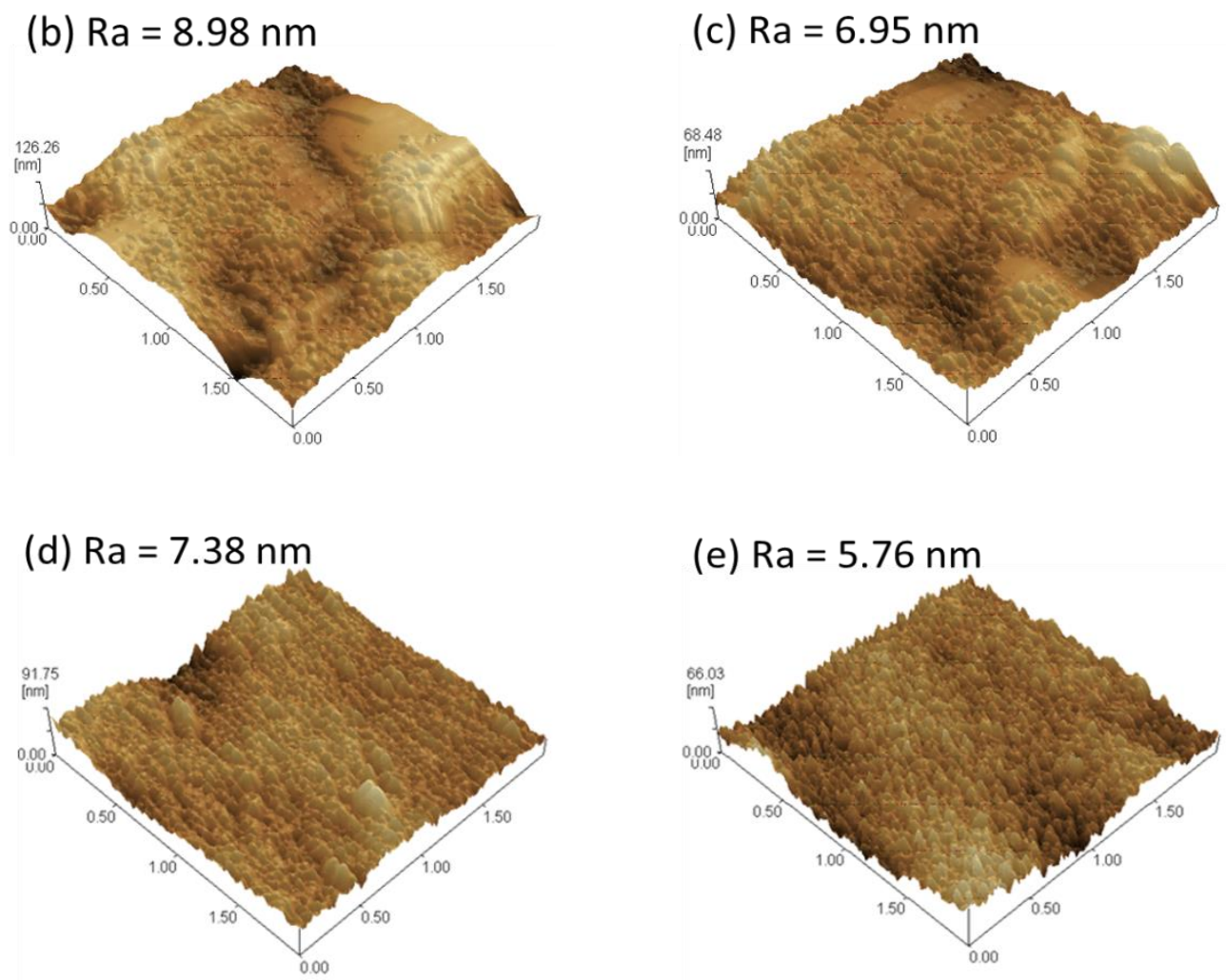

Figure 4. Atomic force microscopy images of uncoated titanium surface (a) and DLC film-coated titanium deposited at $\mathrm{CH}_{4} / \mathrm{H}_{2}=1: 1(\mathbf{b}) ; \mathrm{CH}_{4} / \mathrm{H}_{2}=1: 1$ (c); $\mathrm{CH}_{4} / \mathrm{H}_{2}=1: 0$ (d); $\mathrm{CH}_{4} / \mathrm{H}_{2}=1: 0$ (e), with the deposition times of $6 \mathrm{~h}, 12 \mathrm{~h}, 6 \mathrm{~h}$ and $12 \mathrm{~h}$, respectively.

Figure 5 shows the cross-section SEM images of the DLC films with different deposition conditions, which compactly and densely cover the entire specimen surface. Due to the permeation layer, the thickness of the fully dense film cannot be clearly defined (which was described in Section 2). The a-C:H layer of the fully dense film reaches its maximum thickness of $\sim 1281 \mathrm{~nm}$ as shown in Figure 5d. Figure 5a-c illustrates that the average thickness of the fully dense film is $\sim 533.7 \mathrm{~nm}, 587.1 \mathrm{~nm}$ and $693.9 \mathrm{~nm}$, respectively. With a longer deposition time, the thickness of the fully dense a-C:H layer increases sharply. The titanium substrate can be better prevented from direct corrosion with a larger density of a-C:H coating. With the increase in time, the high-energy ion beams bombard the growing film continuously, thus promoting the DLC atoms penetrating into the specimen with more energy to increase the thickness of the fully dense film and the permeation layer [22].
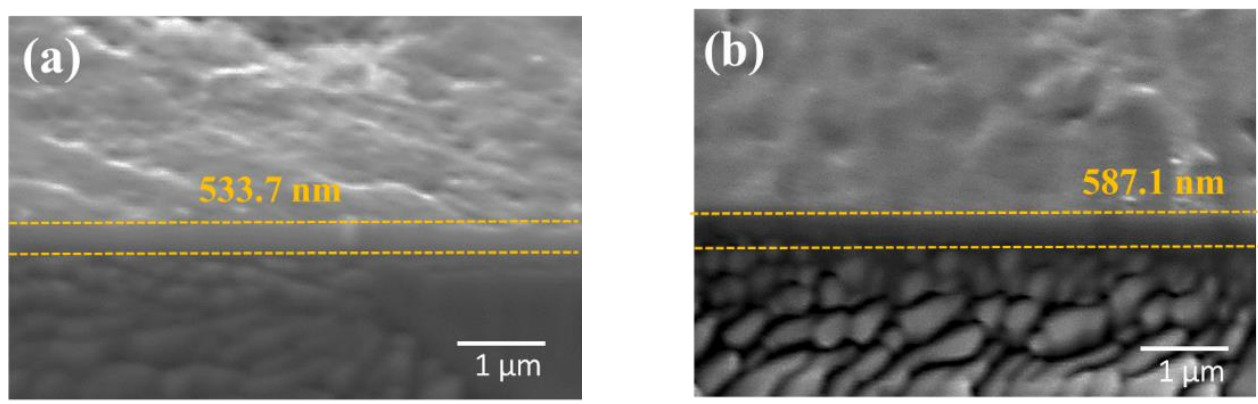

Figure 5. Cont. 

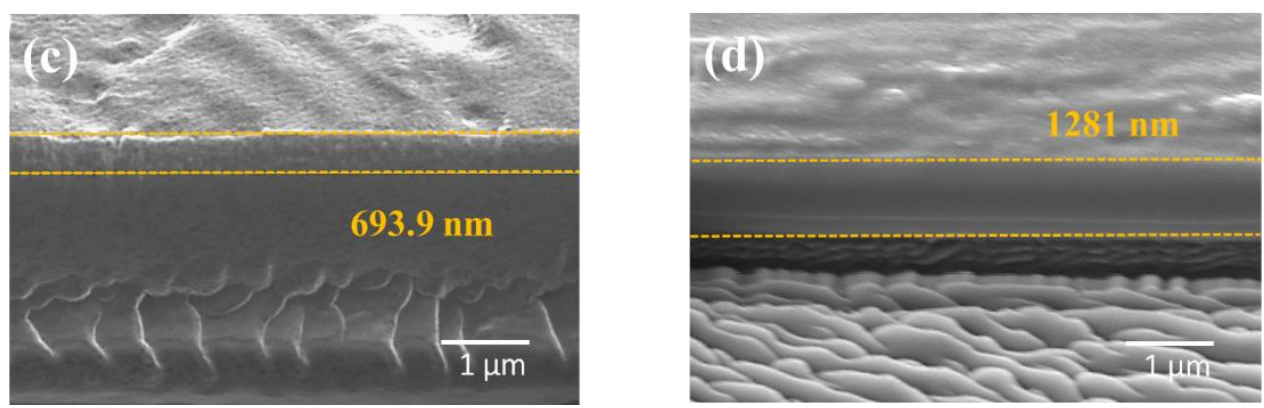

Figure 5. Cross-section SEM images of DLC film-coated titanium deposited at (a) $\mathrm{CH}_{4} / \mathrm{H}_{2}=1: 1,6 \mathrm{~h}$; (b) $\mathrm{CH}_{4} / \mathrm{H}_{2}=1: 1,12 \mathrm{~h}$; (c) $\mathrm{CH}_{4} / \mathrm{H}_{2}=1: 0,6 \mathrm{~h}$; (d) $\mathrm{CH}_{4} / \mathrm{H}_{2}=1: 0,12 \mathrm{~h}$.

In Figure 6, the carbon element concentration distribution and cross-section morphology of the a-C:H coatings are evaluated by EPMA. The element diffusivity of carbon is clearly seen by EPMA mapping. During the ion beam bombardment process, the energetic atomic particles interact with film atoms, drive them into the titanium substrate and produce a graded interface to improve adhesion. Then, the film atoms grow out from the graded interface to form the dense DLC film. As shown in Figure $6 \mathrm{~b}, \mathrm{~d}, \mathrm{f}, \mathrm{h}$, the total thickness of the DLC film, including the dense film and penetration layer, is $\sim 3 \mu \mathrm{m}, 4 \mu \mathrm{m}$, $4 \mu \mathrm{m}$ and $12 \mu \mathrm{m}$, respectively. The carbon concentration on the surface of the DLC coating deposited at $\mathrm{CH}_{4} / \mathrm{H}_{2}=1: 0$ is obviously higher than that of $\mathrm{CH}_{4}=50 \%$. It may be caused by the reaction between the abundance of the $\mathrm{H}$ ions and $\mathrm{C}-\mathrm{C}$ bonds formed on the surface, which reduces the film formation rate.
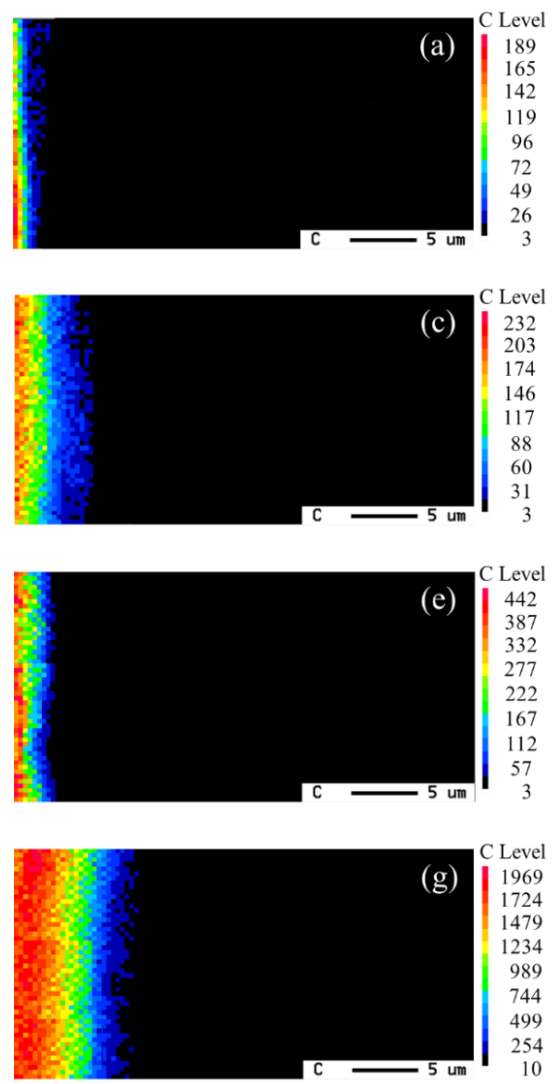
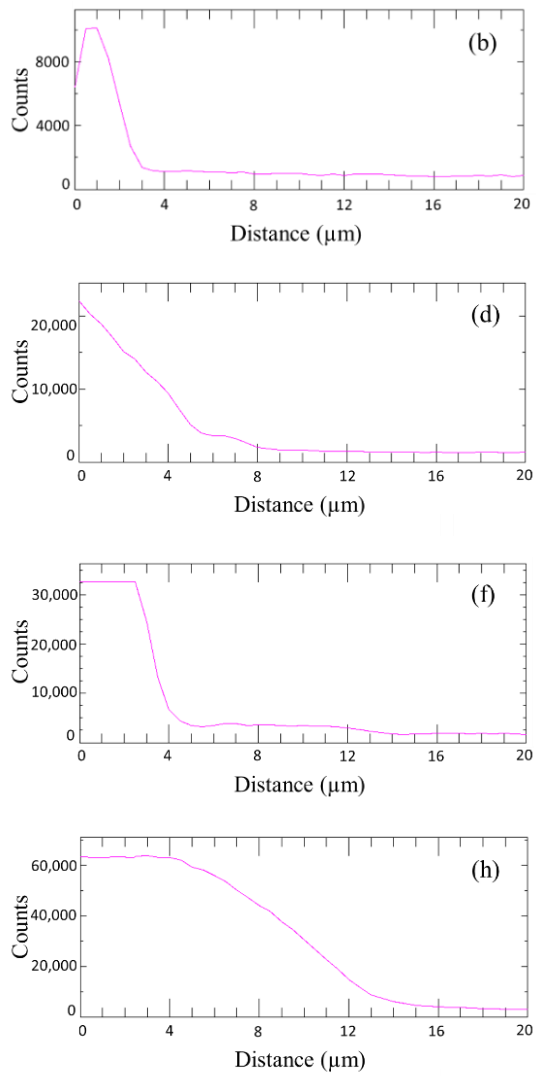

Figure 6. EPMA mapping and line scan of carbon element in the DLC coating cross-section deposited at $(\mathbf{a}, \mathbf{b}) \mathrm{CH}_{4} / \mathrm{H}_{2}=1: 1,6 \mathrm{~h} ;(\mathbf{c}, \mathbf{d}) \mathrm{CH}_{4} / \mathrm{H}_{2}=1: 1,12 \mathrm{~h} ;(\mathbf{e}, \mathbf{f}) \mathrm{CH}_{4} / \mathrm{H}_{2}=1: 0,6 \mathrm{~h} ;(\mathbf{g}, \mathbf{h}) \mathrm{CH}_{4} / \mathrm{H}_{2}=1: 0,12 \mathrm{~h}$. 


\subsection{Raman Analysis}

Three key Raman parameters were used to evaluate the bonding state of the DLC film: the intensity ratio of $\mathrm{D}$ peak to $\mathrm{G}$ peak $\left(\mathrm{I}_{\mathrm{D}} / \mathrm{I}_{\mathrm{G}}\right)$, the full width at half maximum of $\mathrm{G}$ peak (FWHM) and the position of G peak. Figure 7 shows the Raman curves of the a-C:H coatings deposited at different conditions. The $\mathrm{G}$ peak and $\mathrm{D}$ peak are identified at approximately $1560 \mathrm{~cm}^{-1}$ and $1360 \mathrm{~cm}^{-1}$, identifying with the graphite band (arising from breathing modes of $s p^{2}$ atoms in rings) and the disordered band (arising from bond stretching of $s p^{2}$ atoms in rings and chains), respectively [25]. The $G$ peak position and $\mathrm{I}_{\mathrm{D}} / \mathrm{I}_{\mathrm{G}}$ are regarded to have a linear relationship with the graphite crystallite size [26]. FWHM (G) has a greater sensitivity to structure disorder, which originates from the bond length and bond angle. For DLC coatings with $s p^{3}$ content $(>20 \%)$, a shift of the $\mathrm{G}$ peak position to higher wavenumbers is consistent with an increase in $s p^{3}$ [27]. A smaller $\mathrm{I}_{\mathrm{D}} / \mathrm{I}_{\mathrm{G}}$ and higher FWHM (G) can result in a higher coating density [28]. As shown in Figure 7 , as the $\mathrm{I}_{\mathrm{D}} / \mathrm{I}_{\mathrm{G}}$ fraction decreases, the $G$ peak position shifts toward a higher wavenumber. With increasing methane fraction and deposition time, the FWHM $(\mathrm{G})$ increases, which indicates the increasing of the $s p^{3} \mathrm{C}-\mathrm{C}$ bond ratio and the density of the DLC coating. Table 2 shows the detailed Raman parameters. Contrasted with $\mathrm{CH}_{4}=50 \%$, it seems that the effect of increasing $\mathrm{CH}_{4}$ to the precursor gas has a consistent effect of increasing the $s p^{3} \mathrm{C}$ fraction, which may be because $\mathrm{CH}_{4}$ promotes the formation of the $\mathrm{C}-\mathrm{H}$ bond. The a$\mathrm{C}: \mathrm{H}$ film with a low $s p^{3}$ ratio ordinarily indicates low internal stress. High values of compressive stress should be prevented in film growth, nevertheless, it is also found that a moderate compressive stress could be favorable for the anti-corrosion property. Particularly, compressive residual stress can prevent the propagation of delamination through the film layer, which leads to the shrinkage of the open corrosion path in the films.

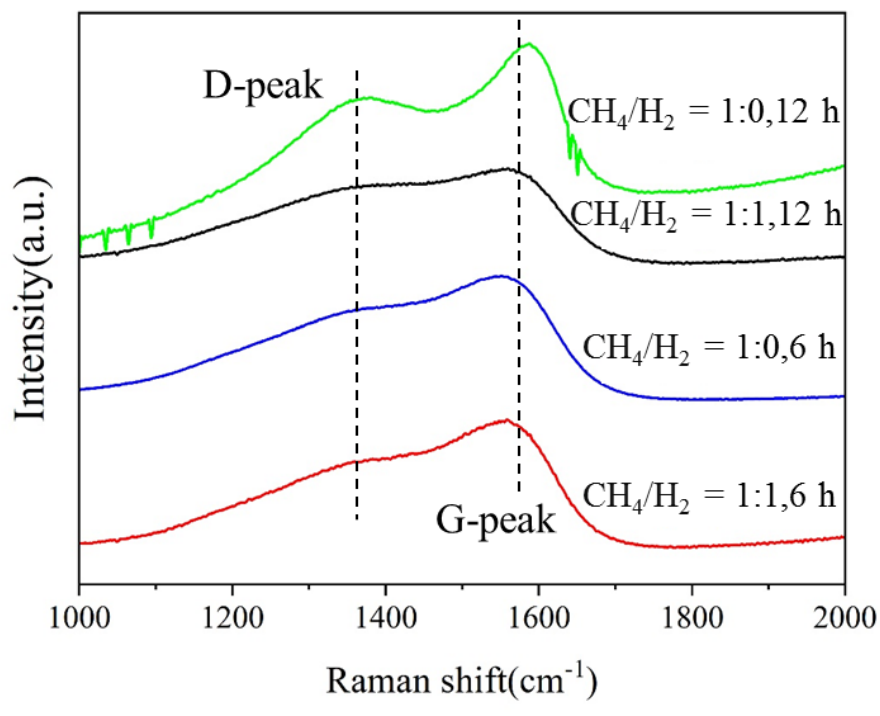

Figure 7. Raman spectrum of DLC film-coated titanium with various deposition conditions.

Table 2. Raman features, i.e., $\mathrm{I}_{\mathrm{D}} / \mathrm{I}_{\mathrm{G}}$ ratio, $\mathrm{G}$ peak position and FWHM $(\mathrm{G})$ of DLC films.

\begin{tabular}{ccccc}
\hline & \multicolumn{2}{c}{$\mathbf{C H}_{4} / \mathbf{H}_{\mathbf{2}}=\mathbf{1 : 1}$} & \multicolumn{2}{c}{$\mathbf{C H}_{\mathbf{4}} / \mathbf{H}_{\mathbf{2}}=\mathbf{1 : 0}$} \\
\hline Deposition time & $6 \mathrm{~h}$ & $12 \mathrm{~h}$ & $6 \mathrm{~h}$ & $12 \mathrm{~h}$ \\
\hline $\mathrm{I}_{\mathrm{D}} / \mathrm{I}_{\mathrm{G}}$ & 0.877 & 0.853 & 0.835 & 0.827 \\
\hline G peak $\left(\mathrm{cm}^{-1}\right)$ & 1556.59 & 1557.96 & 1560.55 & 1565.77 \\
\hline FWHM $(\mathrm{G})\left(\mathrm{cm}^{-1}\right)$ & 133.81 & 134.23 & 135.31 & 138.68 \\
\hline
\end{tabular}




\subsection{TEM Analysis}

The microstructure of the DLC film-coated titanium was evaluated by TEM. Before the experiment, FIB-SEM was used to prepare a sample with a thickness of about $0.1 \mu \mathrm{m}$ for research. As shown in Figure 8a,b, the schematic diagram and TEM micrographs of the DLC film deposited on titanium at $\mathrm{CH}_{4} / \mathrm{H}_{2}=1: 0,12 \mathrm{~h}$ are presented. The local nano-crystals and selected area electron diffraction pattern (SAED) of the amorphous DLC film are also shown in Figure 8c-f. From Figure 8c,e, part A, the amorphous phase microstructure of the pure DLC layer was confirmed by TEM analysis, which is consistent with previous studies $[29,30]$. As we can see in the high-resolution TEM images taken with TiC rings (Figure $8 \mathrm{~d}$, part B), a little TiC nanocrystalline (marked by yellow circles) was surrounded by an amorphous matrix, which suggests that atoms in the DLC have penetrated the metal substrate. The interplanar spacing can be calculated from the diffraction pattern, where $d$ values could be calculated by the following formula:

$$
\lambda \mathrm{L}=\mathrm{rd}
$$

where $r$ is the radius of the diffraction ring, $\lambda$ is the electron beam wavelength and $L$ is the distance of the photo graphic plate from the specimen (the product $\lambda \mathrm{L}=\mathrm{A}$, called the camera constant). As shown in Figure $8 \mathrm{f}$, polycrystalline rings of cubic TiC corresponding to (111), (220) and (222) crystal planes are displayed. The average lattice constant of cubic $\mathrm{TiC}$ acquired from the electron diffraction pattern is $0.250 \mathrm{~nm}$, agreeing well with the result obtained from the TEM micrograph. As shown in Figure 8f, there are no other crystalline diffraction characteristics, indicating that only the cubic $\mathrm{TiC}$ phase exists in the DLC coating with an amorphous hydrocarbon matrix [31]. The nanocrystalline TiC phase has a stable and strong chemical bond energy combining titanium and carbon atoms together, which can be seen from the penetration layer of the DLC coatings. Because of the densification and chemical inertness of the DLC coating, it can protect metal substrate from corrosive solution well.

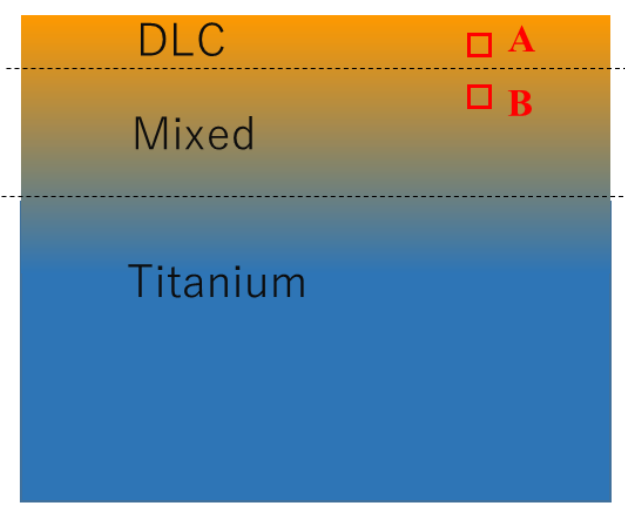

(a)

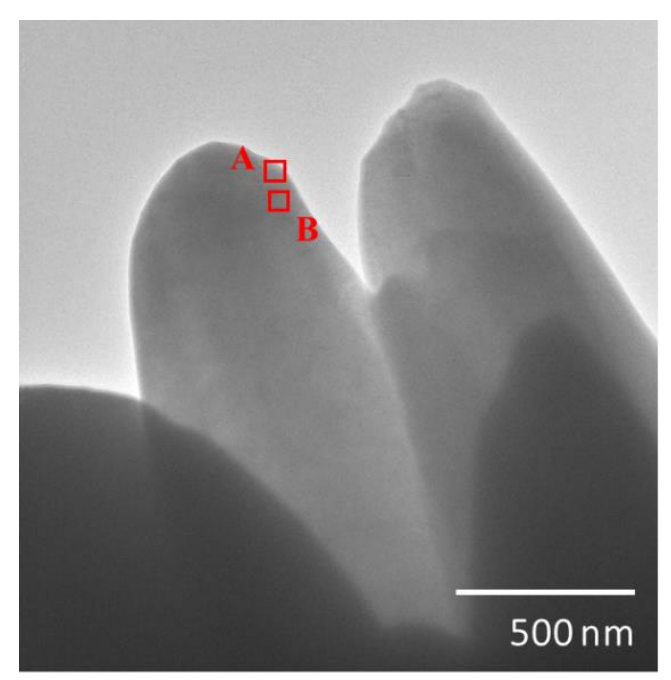

(b)

Figure 8. Cont. 


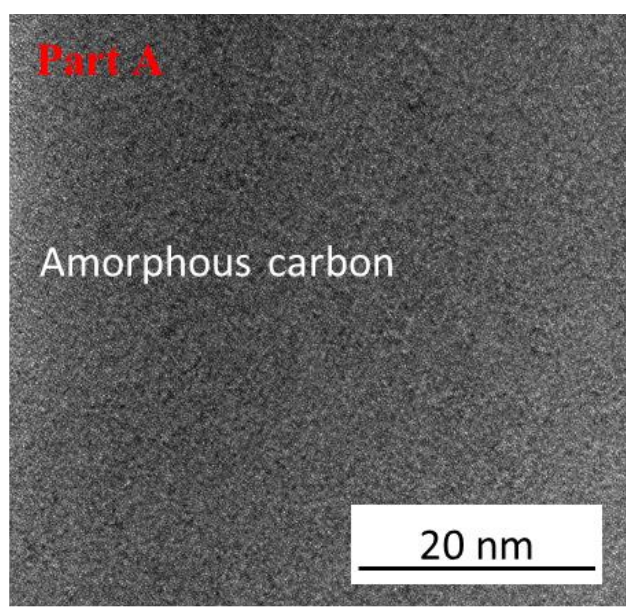

(c)

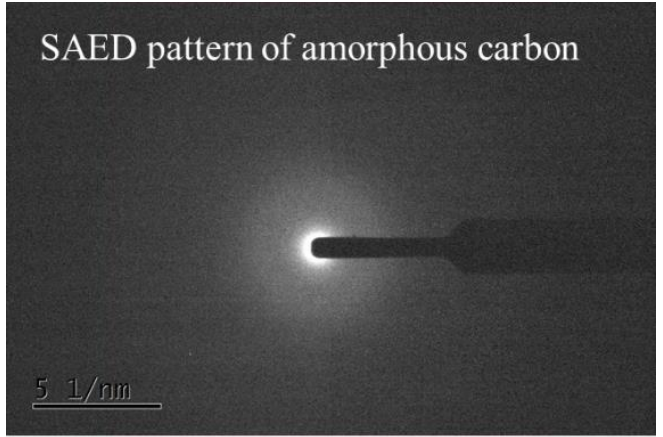

(e)

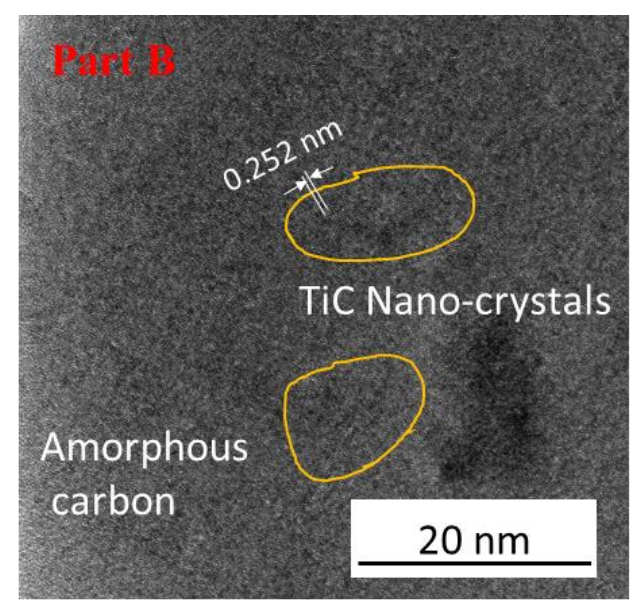

(d)

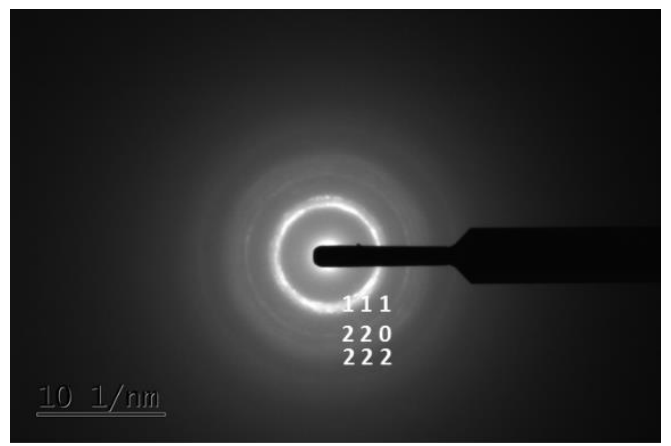

(f)

Figure 8. Schematic diagram (a) and TEM micrograph (b) of the DLC film deposited on titanium at $\mathrm{CH}_{4} / \mathrm{H}_{2}=1: 0,12 \mathrm{~h}$; the selected area is marked with red square: TEM images and SAED patterns of (c) and (e) part A; (d) and (f) part B.

\subsection{XPS Characterization}

To further understand the element composition, the bonding structure of the a-C:H film using different parameters was analyzed by X-ray photoelectron spectroscopy (XPS). In order to obtain a reliable conclusion, $\mathrm{Ar}^{+}$bombardment was used to remove the metal oxide contamination from the environment [32]. The XPS spectrum of C1s of a-C:H film is presented in Figure 9 after removing the metal oxide contamination. The binding energy of $\mathrm{C} 1 \mathrm{~s}$ can be deconvoluted into three parts. The peak located at $285.1 \pm 0.1 \mathrm{eV}, 282 \pm 0.1 \mathrm{eV}$ and $289.1 \pm 0.1 \mathrm{eV}$ is attributed to $\mathrm{C}-\mathrm{C}, \mathrm{Ti}-\mathrm{C}$ and $\mathrm{O}-\mathrm{C}=\mathrm{O}$, respectively, which are the main functional groups on the surface of a-C:H coatings [33]. The Ti-C bond is observed in the XPS spectrum, demonstrating the strong adhesion force between the DLC film and the substrate. The oxygen percentage of DLC coatings deposited at the condition of $\mathrm{CH}_{4}=50 \%$, $6 \mathrm{~h} ; \mathrm{CH}_{4}=50 \%, 12 \mathrm{~h} ; \mathrm{CH}_{4}=100 \%, 6 \mathrm{~h}$; and $\mathrm{CH}_{4}=100 \%, 12 \mathrm{~h}$ is $~ 35.1 \%, 31.8 \%, 31.7 \%$ and $23.3 \%$, respectively, indicating that it gradually decreases with the deposition time. It is well known that a-C:H film with less $\mathrm{C}=\mathrm{O}$ and $\mathrm{C}-\mathrm{O}$ bonds suggest a denser coating [34]. 

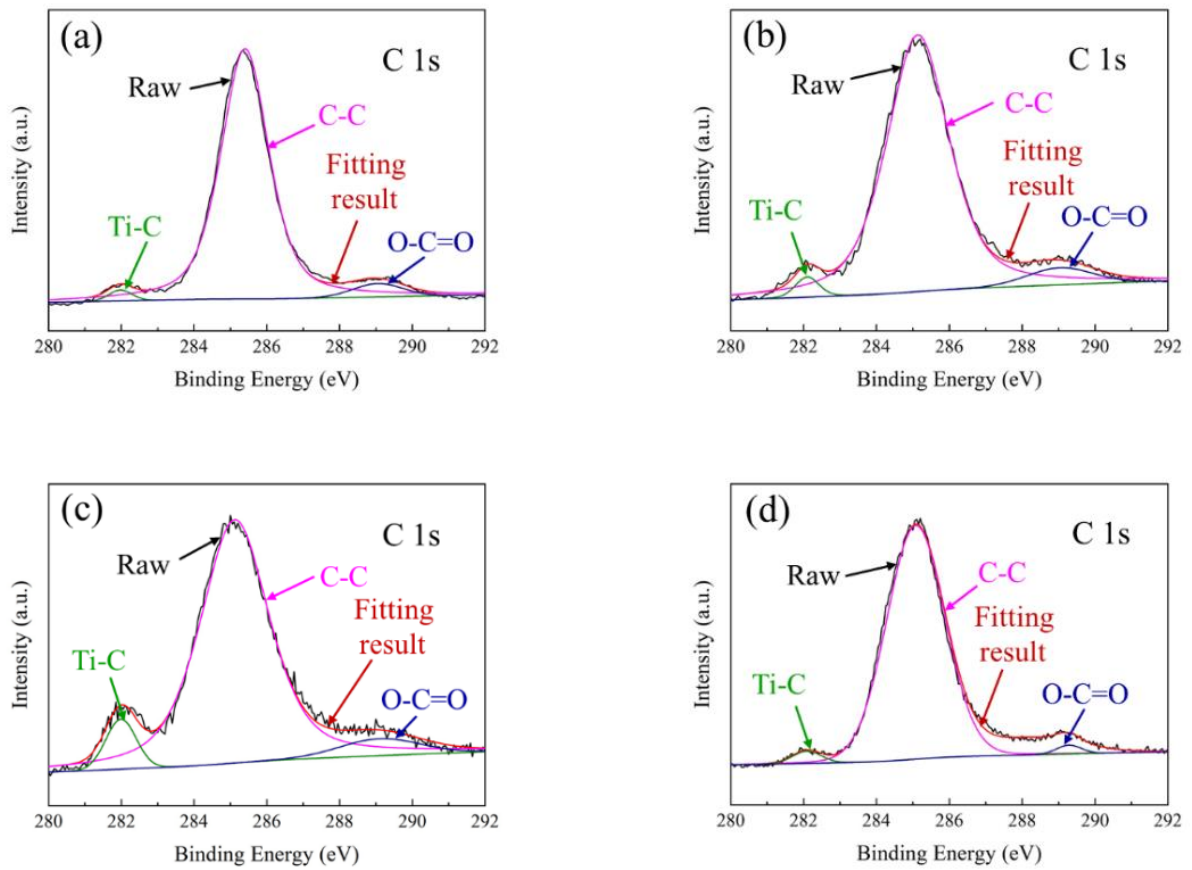

Figure 9. $\mathrm{C} 1 \mathrm{~s}$ XPS spectrum of DLC film deposited on titanium at (a) $\mathrm{CH}_{4} / \mathrm{H}_{2}=1: 1,6 \mathrm{~h}$; (b) $\mathrm{CH}_{4} / \mathrm{H}_{2}=1: 1,12 \mathrm{~h}$; (c) $\mathrm{CH}_{4} / \mathrm{H}_{2}=1: 0,6 \mathrm{~h}$; (d) $\mathrm{CH}_{4} / \mathrm{H}_{2}=1: 0,12 \mathrm{~h}$.

\subsection{ICR Test}

The key to improving the output power efficiency of PEMFC is ensuring that the metallic bipolar plate has a high conductivity. Therefore, subtracting the resistance of the substrate from the resistance of the a-C:H film-coated titanium can obtain the value of the ICR [35]. Table 3 shows the ICR result of DLC film at $150 \mathrm{~N} / \mathrm{cm}^{2}$. The DLC film deposited at the condition of $\mathrm{CH}_{4}=50 \%$ and $6 \mathrm{~h}$ shows the lowest resistance of $7 \mathrm{~m} \Omega \cdot \mathrm{cm}^{2}$. It meets the Department of Energy's (DOE) target $\left(10 \mathrm{~m} \Omega \cdot \mathrm{cm}^{2}\right.$, year 2020). If the $\mathrm{CH}_{4}$ ratio decreases to $50 \%$, the ICR will increase because of its good conductive performance from the high content of $\mathrm{sp}^{2} \mathrm{C}$ bonds. The ICR identifies with the Raman spectroscopy.

Table 3. ICR of DLC films using different conditions.

\begin{tabular}{ccccc}
\hline & \multicolumn{2}{c}{$\mathbf{C H}_{\mathbf{4}} / \mathbf{H}_{\mathbf{2}}=\mathbf{1 : 1}$} & \multicolumn{2}{c}{$\mathbf{C H}_{\mathbf{4}} / \mathbf{H}_{\mathbf{2}}=\mathbf{1 : 0}$} \\
\hline Deposition time & $6 \mathrm{~h}$ & $12 \mathrm{~h}$ & $6 \mathrm{~h}$ & $12 \mathrm{~h}$ \\
$\mathrm{ICR}\left(\mathrm{m} \Omega \cdot \mathrm{cm}^{2}\right)$ & 7 & 17.3 & 16.5 & 22.4 \\
\hline
\end{tabular}

\subsection{Corrosion Behavior of DLC Film}

Figure 10 presents the surface morphology on the uncoated and DLC film-coated titanium after the corrosion test. The bare substrate was destroyed; meanwhile, some cracks appeared on the surface as shown in Figure 10a. The area of localized corrosion becomes larger as $\mathrm{CH}_{4}=100 \%$ decreases to $\mathrm{CH}_{4}=50 \%$. During the $168 \mathrm{~h}$ corrosion test in a high temperature acid solution, there exists pitting corrosion, which has been marked with red circles. It was caused by the sulfuric acid solution penetrating into the DLC coating and contacting with the bare Ti substrate. Moreover, the pitting phenomenon also resulted in the acceleration of corrosion in the local region, while causing the film to peel off.

In Figure 11, the Raman spectrum of a-C:H coatings are shown, in which the films are treated with different deposition parameters after the potentiostatic corrosion. The $\mathrm{G}$ peak position shifted toward a higher wavenumber and the $s p^{3} \mathrm{C}$ ratio increased compared with the Raman analysis before the corrosion test. We speculate that a small amount of the film was peeled off from the surface of the sample. The anti-corrosion behavior of $\mathrm{a}-\mathrm{C}: \mathrm{H}$ coatings deposited at $12 \mathrm{~h}$ with smoother curves is better than that of a-C:H coatings 
deposited at $6 \mathrm{~h}$, according to the Raman spectrum analysis. Moreover, the peak intensity of a-C: $\mathrm{H}$ coatings become stronger at $\mathrm{CH}_{4}=100 \%$.

After the potentiostatic corrosion test for $168 \mathrm{~h}$, the concentration of the dissolved metal ion in the sulfuric acid corrosion solution was measured by ICP. Table 4 shows the results of the metal specimen and a-C:H coatings. Contrary to the bare specimen (about $0.58 \mathrm{ppm}$ ), the metal ions dissolved in the liquid have significantly reduced $(0.34 \mathrm{ppm} \sim 0.49 \mathrm{ppm})$, which indicated that the a-C:H coating plays a key role in protecting the titanium substrate. The hydrogen ions in an acid environment would form a strong corrosion layer to accelerate the corrosion [36]. It is obvious that the concentration of $\mathrm{Ti}^{4+}$ in a-C:H coatings formed in a $100 \% \mathrm{CH} 4$ atmosphere, as $0.34 \mathrm{ppm}$ for $12 \mathrm{~h}$ is lower than that of other conditions. The higher density of a-C:H coatings with $\mathrm{CH}_{4}=100 \%$ has an important effect on preventing the corrosive solution from reacting with the metal substrate. Even the DLC film deposited at $\mathrm{CH}_{4} / \mathrm{H}_{2}=1: 0,6 \mathrm{~h}$, is lower than that at $\mathrm{CH}_{4} / \mathrm{H}_{2}=1: 1,12 \mathrm{~h}$. The smoother surface of a-C:H coatings has a higher anti-corrosion ability due to the smaller exposed area in the corrosive environment. The high oxygen content of a-C:H coatings deposited at $\mathrm{CH}_{4}=50 \%$ can accelerate corrosion in an acid solution as well. The conclusion is in agreement with the AFM and SEM results.
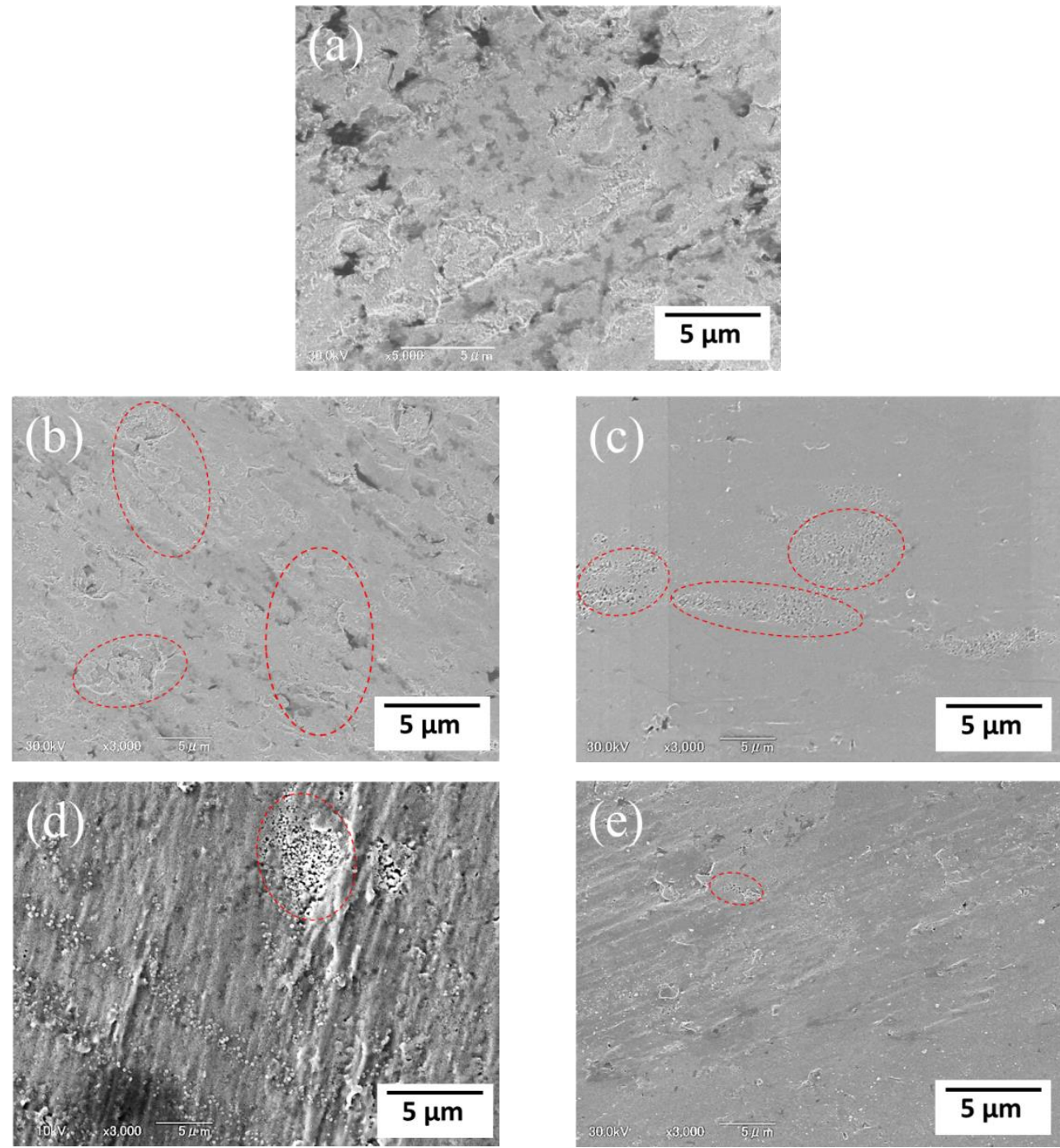

Figure 10. SEM images of uncoated titanium (a) and DLC films deposited at $\mathrm{CH}_{4} / \mathrm{H}_{2}=1: 1,6 \mathrm{~h}$ (b); $\mathrm{CH}_{4} / \mathrm{H}_{2}=1: 1,12 \mathrm{~h}$ (c); $\mathrm{CH}_{4} / \mathrm{H}_{2}=1: 0,6 \mathrm{~h}(\mathbf{d}) ; \mathrm{CH}_{4} / \mathrm{H}_{2}=1: 0,12 \mathrm{~h}(\mathbf{e})$. 

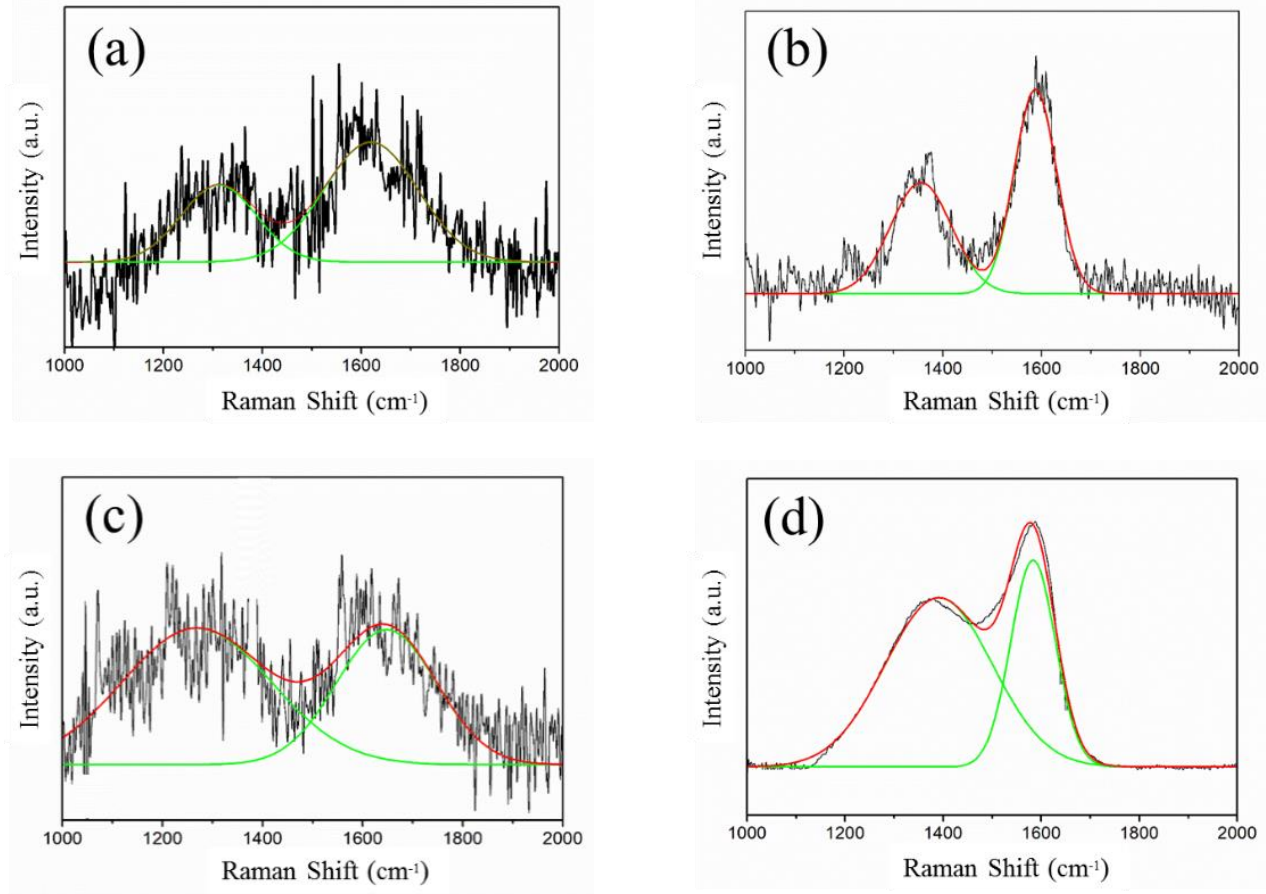

Figure 11. Typical Raman spectrum of DLC films deposited on titanium at (a) $\mathrm{CH}_{4} / \mathrm{H}_{2}=1: 1,6 \mathrm{~h}$; (b) $\mathrm{CH}_{4} / \mathrm{H}_{2}=1: 1,12 \mathrm{~h}$; (c) $\mathrm{CH}_{4} / \mathrm{H}_{2}=1: 0,6 \mathrm{~h}$; (d) $\mathrm{CH}_{4} / \mathrm{H}_{2}=1: 0,12 \mathrm{~h}$.

Table 4. Metal ion concentration for the bare and DLC film-coated titanium after $168 \mathrm{~h}$ corrosion.

\begin{tabular}{cccccc}
\hline & Substrate & \multicolumn{2}{c}{$\mathbf{C H}_{\mathbf{4}} / \mathbf{H}_{\mathbf{2}}=\mathbf{1 : 1}$} & \multicolumn{2}{c}{$\mathbf{C H}_{\mathbf{4}} / \mathbf{H}_{\mathbf{2}}=\mathbf{1 : 0}$} \\
\hline Deposition time & & $6 \mathrm{~h}$ & $12 \mathrm{~h}$ & $6 \mathrm{~h}$ & $12 \mathrm{~h}$ \\
ICP $(\mathrm{ppm})$ & 0.58 & 0.49 & 0.43 & 0.37 & 0.34 \\
\hline
\end{tabular}

As shown in Figure 12, the polarization curve of Ti substrate and a-C:H coatings in $0.5 \mathrm{~mol} / \mathrm{L}$ sulfuric acid solution purged with air at $90{ }^{\circ} \mathrm{C}$ is displayed. The high active peak of uncoated titanium can be clearly seen due to active dissolution and formation of non-conductive oxide scale. Compared with metal substrate, DLC films coated on titanium show a higher corrosion potential and a more stable passivation zone under simulated fuel cell conditions. Under the condition of gas ratio $\mathrm{CH}_{4}=100 \%$ and $12 \mathrm{~h}$, the maximum corrosion potential of $\sim 0.15 \mathrm{~V}$ is obtained, which is much higher than the uncoated substrate of $\sim-0.34 \mathrm{~V}$. It is known that a high corrosion potential usually means an excellent anticorrosion performance due to the noble electrochemical behavior [37]. Compared with the bare specimen (where the corrosion electric current density is $\sim 1.8 \mu \mathrm{A} / \mathrm{cm}^{2}$ ), the corrosion current density of DLC film-coated titanium is decreased to the minimum (of $\sim 0.23 \mu \mathrm{A} / \mathrm{cm}^{2}$, at the condition of $\mathrm{CH}_{4} 100 \%$ and $12 \mathrm{~h}$ ) under the actual operation environment where the cathode potential is about $0.6 \mathrm{~V}$. All the corrosion current densities of the DLC films coated on titanium meet the DOE's target (2020) of $1 \mu \mathrm{A} / \mathrm{cm}^{2}(0.5 \mathrm{~mol} / \mathrm{L}$ sulfuric acid solution with $5 \mathrm{ppm} \mathrm{HF}$ at $70^{\circ} \mathrm{C}$ ). The smaller corrosion current density usually implies a smaller corrosion rate. The electrochemical performance of different DLC films coated on titanium is similar on the polarization curves. The DLC films on the substrate can protect titanium from reacting with the sulfuric acid solution to prevent metal corrosion. DLC film using the condition of gas ratio $\mathrm{CH}_{4} 100 \%$ and a longer deposition time of $12 \mathrm{~h}$ has a more stable electrochemical property and a better anti-corrosion performance because of the inherent microstructure characteristic, which can be contrasted by the SEM analysis. The electrochemical behavior is not carried out in the anode environment because the corrosion is relatively weak compared with the environment of the cathode [35]. 


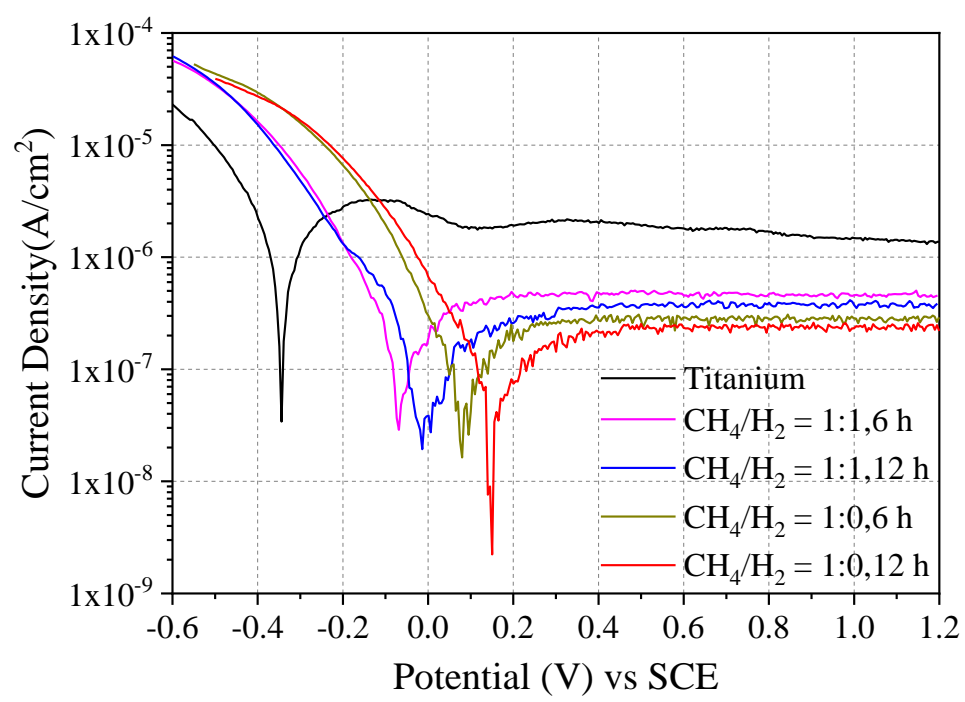

Figure 12. Potentiodynamic behaviors of uncoated titanium and various DLC films coated on titanium in $0.5 \mathrm{~mol} / \mathrm{L} \mathrm{H}_{2} \mathrm{SO}_{4}$ at $90{ }^{\circ} \mathrm{C}$.

\section{Conclusions}

The a-C:H/DLC film on titanium substrate as a protective film was formed using the IBD method by changing the $\mathrm{CH}_{4} / \mathrm{H}_{2}$ ratio and deposition time for PEMFC. The IBD technique has many advantages, such as lower compressive stress because of the existence of a graded interfacial, higher film-substrate adhesion and better surface characteristics of high precision parts. The chemical composition and corrosion property of the DLC coatings were analyzed. The following conclusions are drawn:

The surface roughness and $\mathrm{I}_{\mathrm{D}} / \mathrm{I}_{\mathrm{G}}$ fraction of the a-C:H/DLC coating deposited at $\mathrm{CH}_{4} / \mathrm{H}_{2}=1: 0$ are lower, while they decrease with the increasing deposition time. The $\mathrm{I}_{\mathrm{D}} / \mathrm{I}_{\mathrm{G}}$ fraction decreases to a minimum of 0.827 at $\mathrm{CH}_{4} / \mathrm{H}_{2}=1: 0,12 \mathrm{~h}$, indicating the highest $s p^{3}$ bond fraction, mainly because the $\mathrm{CH}_{4}$ promotes the formation of the $\mathrm{C}-\mathrm{H}$ bond. The ICR reduced to $7 \mathrm{~m} \Omega \cdot \mathrm{cm}^{2}$ at $\mathrm{CH}_{4} / \mathrm{H}_{2}=1: 1,6 \mathrm{~h}$, because of the high $s p^{2} \mathrm{C}$ content. The thickness of the DLC film decreases with the introduction of hydrogen due to the etching effect of $\mathrm{H}$ ions. The cubic TiC phase found from the penetration layer has a stable and strong chemical bond energy.

The a-C: $\mathrm{H}$ coating deposited at $\mathrm{CH}_{4}=100 \%$ is denser than that at $\mathrm{CH}_{4}=50 \%$ from the SEM analysis. With the parameter of $\mathrm{CH}_{4}=100 \%, 12 \mathrm{~h}$, the a-C:H coating has the lowest titanium ion concentration of $0.34 \mathrm{ppm}$ with the maximum thickness of about $12 \mu \mathrm{m}$, which indicate the best anti-corrosion behavior because the a-C:H coating is dense from the surface morphology. Compared with the bare specimen, the DLC specimen reveals the highest corrosion potential of $0.15 \mathrm{~V}$ and the lowest corrosion current density of $0.23 \mu \mathrm{A} / \mathrm{cm}^{2}$. This higher electrochemical stability implied a better anti-corrosion property. All the corrosion current densities of the DLC films meet the DOE's 2020 target of $1 \mu \mathrm{A} / \mathrm{cm}^{2}$. The pitting corrosion occurs in the passivation layer because of a self-excited reaction. Meanwhile, some pores are formed on the surface, which can accelerate the corrosion rate and cause the film to peel off. However, the nanocrystalline $\mathrm{TiC}$ phase in the penetration layer inhibits this behavior due to the enhanced adhesion.

Therefore, the a-C:H coating deposited on the Ti substrate by the IBD method at $\mathrm{CH}_{4} / \mathrm{H}_{2}=1: 0$ has the better corrosion inhibition property resistance. As a result, the DLC coating is helpful to decrease the rate of corrosion and can be considered as a candidate bipolar plate for PEMFCs. 
Author Contributions: Conceptualization, B.H. and M.Y.; methodology, B.H., M.Y. and D.J.; software, B.H.; validation, B.H., M.C., S.S. and D.J.; writing-original draft preparation, B.H.; writing-review and editing, M.Y., M.C., S.S. and D.J. All authors have read and agreed to the published version of the manuscript.

Funding: This research was funded by State Power Investment Corporation and Ningbo Institute of Materials Industry Innovation in China.

Institutional Review Board Statement: Not Applicable.

Informed Consent Statement: Not Applicable.

Data Availability Statement: The data provided in this study could be released upon logical requests.

Acknowledgments: This work was supported by State Power Investment Corporation, Ningbo Institute of Materials Industry Innovation, National Natural Science Foundation of China (11932005) and Key R \& D projects in Zhejiang Province (2021C01101) in China.

Conflicts of Interest: The authors declare no conflict of interest.

\section{References}

1. Dodds, P.E.; Staffell, I.; Hawkes, A.; Li, F.G.N.; Grunewald, P.; Mcdowall, W.; Ekins, P. Hydrogen and fuel cell technologies for heating: A review. Int. J. Hydrogen Energy 2015, 40, 2065-2083. [CrossRef]

2. Kumagai, M.; Myung, S.; Kuwata, S.; Asaishi, R.; Katada, Y.; Yashiro, H. Application of ni-free high nitrogen stainless steel for bipolar plates of proton exchange membrane fuel cells. Electrochim. Acta 2009, 54, 1127-1133. [CrossRef]

3. Dhakate, S.R.; Sharma, S.P.; Borah, M.; Mathur, R.B.; Dhami, T.L. Expanded graphite-based electrically conductive composites as bipolar plate for pem fuel cell. Int. J. Hydrogen Energy 2008, 33, 7146-7152. [CrossRef]

4. Asri, N.F.; Husaini, T.; Sulong, A.B.; Majlan, E.H.; Daud, W.R.W. Coating of stainless steel and titanium bipolar plates for anticorrosion in pemfc: A review. Int. J. Hydrogen Energy 2017, 42, 9135-9148. [CrossRef]

5. Mawdsley, J.; Carter, J.D.; Wang, X.; Niyogi, S.; Fan, C.Q.; Koc, R.; Osterhout, G. Composite-coated aluminum bipolar plates for pem fuel cells. J. Power Sources 2013, 231, 106-112. [CrossRef]

6. Hatada, R.; Flege, S.; Bobrich, A.; Ensinger, W.; Baba, K. Surface modification and corrosion properties of implanted and dlc coated stainless steel by plasma based ion implantation and deposition. Surf. Coat. Technol. 2014, 256, 23-29. [CrossRef]

7. Mingge, W.; Congda, L.; Tao, H.; Guohai, C.; Donghui, W.; Haifeng, Z.; Dong, Z.; Aiying, W. Chromium interlayer amorphous carbon film for 304 stainless steel bipolar plate of proton exchange membrane fuel cell. Surf. Coat. Technol. 2016, 307, 374-381. [CrossRef]

8. Lee, S.; Kakati, N.; Maiti, J.; Jee, S.H.; Kalita, D.J.; Yoon, Y.S. Corrosion and electrical properties of crn- and tin-coated 3161 stainless steel used as bipolar plates for polymer electrolyte membrane fuel cells. Thin Solid Film. 2013, 529, 374-379. [CrossRef]

9. Lin, Y.; Lin, H.; Liu, C.; Huang, M.; Chen, J.; Shih, H.C. Structure and characterization of the multilayered ti-dlc films by fcva. Diam. Relat. Mater. 2010, 19, 1034-1039. [CrossRef]

10. Yatsuzuka, M.; Tateiwa, J.; Uchida, H. Evaluation of pinhole defect in dlc film prepared by hybrid process of plasma-based ion implantation and deposition. Vacuum 2006, 80, 1351-1355. [CrossRef]

11. Toro, R.G.; Calandra, P.; Cortese, B.; De Caro, T.; Brucale, M.; Mezzi, A.; Federici, F.; Caschera, D. Argon and hydrogen plasma influence on the protective properties of diamond-like carbon films as barrier coating. Surf. Interfaces 2017, 6, 60-71. [CrossRef]

12. Lin, K.; Li, X.; Tian, L.; Dong, H. Active screen plasma surface co-alloying of 316 austenitic stainless steel with both nitrogen and niobium for the application of bipolar plates in proton exchange membrane fuel cells. Int. J. Hydrogen Energy 2015, 40, 10281-10292. [CrossRef]

13. Zhang, H.; Hou, M.; Lin, G.; Han, Z.; Fu, Y.; Sun, S.; Shao, Z.; Yi, B. Performance of ti-ag-deposited titanium bipolar plates in simulated unitized regenerative fuel cell (urfc) environment. Int. J. Hydrogen Energy 2011, 36, 5695-5701. [CrossRef]

14. Jung, H.; Huang, S.; Ganesan, P.; Popov, B.N. Performance of gold-coated titanium bipolar plates in unitized regenerative fuel cell operation. J. Power Sources 2009, 194, 972-975. [CrossRef]

15. Han, B.B.; Ju, D.Y.; Chai, M.R.; Zhao, H.J.; Sato, S. Corrosion resistance of dlc film-coated sus3161 steel prepared by ion beam enhanced deposition. Adv. Mater. Sci. Eng. 2019, 2019, 1-13. [CrossRef]

16. Liu, X.; Kavanagh, J.; Matthews, A.; Leyland, A. The combined effects of $\mathrm{cu}$ and ag on the nanostructure and mechanical properties of crcuagn pvd coatings. Surf. Coat. Technol. 2015, 284, 101-111. [CrossRef]

17. Sioshansi, P.; Tobin, E.J. Surface treatment of biomaterials by ion beam processes. Surf. Coat. Technol. 1996, 83, 175-182. [CrossRef]

18. Martigonzalez, J.; Bertran, E. Mechanical and surface characterization of diamond-like carbon coatings onto polymeric substrate. arXiv 2015, arXiv:1509.08512.

19. Voevodin, A.A.; Donley, M.S.; Zabinski, J.S. Pulsed laser deposition of diamond-like carbon wear protective coatings: A review. Surf. Coat. Technol. 1997, 92, 42-49. [CrossRef] 
20. Kesavan, T.; Partheeban, T.; Vivekanantha, M.; Kundu, M.; Maduraiveeran, G.; Sasidharan, M. Hierarchical nanoporous activated carbon as potential electrode materials for high performance electrochemical supercapacitor. Microporous Mesoporous Mater. 2019, 274, 236-244. [CrossRef]

21. Feng, K.; Cai, X.; Sun, H.; Li, Z.; Chu, P.K. Carbon coated stainless steel bipolar plates in polymer electrolyte membrane fuel cells. Diam. Relat. Mater. 2010, 19, 1354-1361. [CrossRef]

22. Ortizmedina, J.; Kitano, H.; Morelosgomez, A.; Wang, Z.; Araki, T.; Kang, C.; Hayashi, T.; Takeuchi, K.; Kawaguchi, T.; Tanioka, A. Nanostructured carbon-based membranes: Nitrogen doping effects on reverse osmosis performance. NPG Asia Mater. $2016,8$.

23. Ding, W.; Guo, Y.; Ju, D.Y.; Sato, S.; Tsunoda, T. The effect of $\mathrm{CH}_{4} / \mathrm{H}_{2}$ ratio on the surface properties of hdpe treated by chx ion beam bombardment. Mod. Phys. Lett. B 2016, 30, 1650214. [CrossRef]

24. Liang, J.H.; Chen, M.H.; Tsai, W.F.; Lee, S.C.; Ai, C.F. Characteristics of diamond-like carbon film synthesized on aisi 304 austenite stainless steel using plasma immersion ion implantation and deposition. Nucl. Instrum. Methods Phys. Res. Sect. B Beam Interact. Mater. At. 2007, 257, 696-701. [CrossRef]

25. Han, B.; Ju, D.; Sato, S.; Zhao, H. Plasma preparation method and tribological properties of diamond-like carbon coating on magnesium alloy az31 substrate. Sci. China-Technol. Sci. 2019, 62, 1939-1947. [CrossRef]

26. Kato, H.; Itagaki, N.; Im, H.J. Growth and raman spectroscopy of thickness-controlled rotationally faulted multilayer graphene. Carbon 2019, 141, 76-82. [CrossRef]

27. Dwivedi, N.; Rismaniyazdi, E.; Yeo, R.J.; Goohpattader, P.S.; Satyanarayana, N.; Srinivasan, N.; Druz, B.; Tripathy, S.; Bhatia, C.S Probing the role of an atomically thin sinx interlayer on the structure of ultrathin carbon films. Sci. Rep. 2015, 4, 5021. [CrossRef]

28. Gao, K.; Wang, Y.; Wei, X.; Qiang, L.; Zhang, B.; Zhang, J. Hydrogenated amorphous carbon films with different nanostructure: A comparative study. Chem. Phys. Lett. 2019, 715, 330-334. [CrossRef]

29. Ghosh, B.; Guzmanolivos, F.; Espinozagonzalez, R. Plasmon-enhanced optical absorption with graded bandgap in diamond-like carbon (dlc) films. J. Mater. Sci. 2017, 52, 218-228. [CrossRef]

30. Jo, Y.J.; Zhang, T.F.; Son, M.J.; Kim, K.H. Synthesis and electrochemical properties of ti-doped dlc films by a hybrid pvd/pecvd process. Appl. Surf. Sci. 2018, 433, 1184-1191. [CrossRef]

31. Meng, W.J.; Gillispie, B.A. Mechanical properties of ti-containing and w-containing diamond-like carbon coatings. J. Appl. Phys. 1998, 84, 4314-4321. [CrossRef]

32. Guo, T.; Kong, C.; Li, X.; Guo, P.; Wang, Z.; Wang, A. Microstructure and mechanical properties of ti/al co-doped dlc films: Dependence on sputtering current, source gas, and substrate bias. Appl. Surf. Sci. 2017, 410, 51-59. [CrossRef]

33. Magnuson, M.; Lewin, E.; Hultman, L.; Jansson, U. Electronic structure and chemical bonding of nanocrystalline-tic/amorphous-c nanocomposites. Phys. Rev. B 2009, 80, 235108. [CrossRef]

34. Mangolini, F.; Krick, B.A.; Jacobs, T.D.B.; Khanal, S.; Streller, F.; Mcclimon, J.B.; Hilbert, J.; Prasad, S.V.; Scharf, T.W.; Ohlhausen, J.A. Effect of silicon and oxygen dopants on the stability of hydrogenated amorphous carbon under harsh environmental conditions. Carbon 2018, 130, 127-136. [CrossRef]

35. Huang, N.B.; Yu, H.; Xu, L.; Zhan, S.; Sun, M.; Kirk, D.W. Corrosion kinetics of 3161 stainless steel bipolar plate with chromiumcarbide coating in simulated pemfc cathodic environment. Results Phys. 2016, 6, 730-736. [CrossRef]

36. Yoshida, M.; Tanaka, T.; Watanabe, S.; Shinohara, M.; Lee, J.; Takagi, T. Improvement of oxygen barrier of pet film with diamond-like carbon film by plasma-source ion implantation. Surf. Coat. Technol. 2003, 174, 1033-1037. [CrossRef]

37. Lyons, K.S.; Gould, B.D. Lightweight titanium metal bipolar plates for pem fuel cells. Mater. Sci. Forum 2016, 879, 613-618. [CrossRef] 